\title{
Teaching Neuroimages: COVID-19-Associated Acute Disseminated Encephalomyelitis With Corpus Callosal Hemorrhage
}

Christopher Green, FRCR, * Hamish Morrison, MRCP, * Paul Smith, FRCR, Farhad Golestani, FRCP, MD, Claire Rice, FRCP, PhD, Elizabeth Coulthard, FRCP, PhD, Julie Searle, FRCR, and lain Lyburn, FRCR

Neurology ${ }^{\circledR}$ 2021;96:e307-e308. doi:10.1212/WNL.0000000000011001

Figure Brain MRI and CT

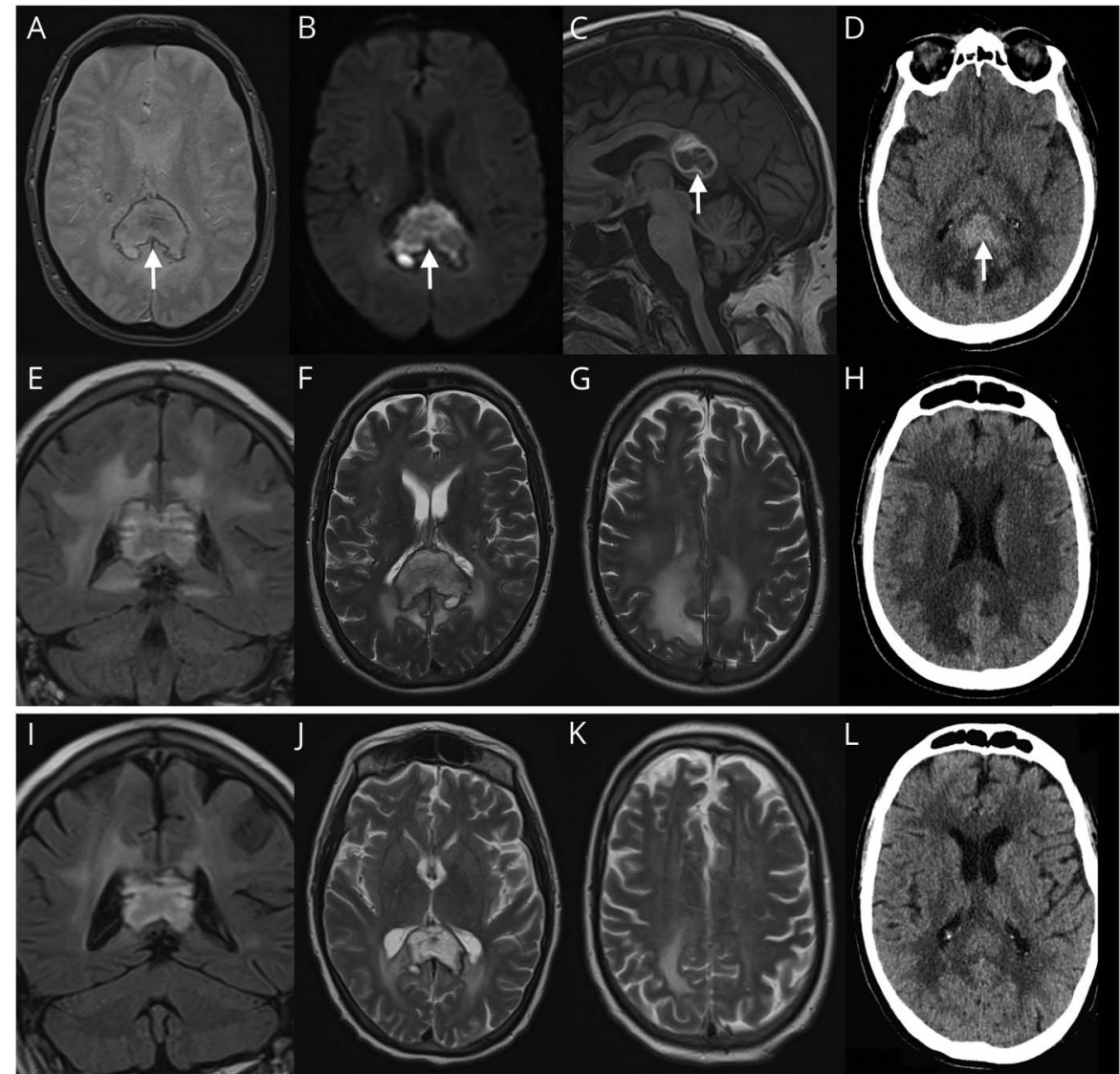

Initial MRI and CT with arrows highlighting peripheral low signal on T2* (A), abnormal diffusion (B), high T1 (C), and increased attenuation (D) within the corpus callosum splenium. Confluent high FLAIR (E) and T2 (F and G) abnormality and low attenuation $(\mathrm{H})$ are noted within the deep cerebral white matter. Improved appearances at 2 weeks are seen $(\mathrm{I}-\mathrm{L})$.

A 55-year-old man with severe coronavirus disease 2019 (COVID-19) required ventilation and hemofiltration. Central venous catheter thrombosis necessitated heparin infusion. On day 20 postadmission, impaired conscious level, complex ophthalmoplegia, and hyperreflexia prompted noncontrast neuroimaging, demonstrating corpus callosal and right subinsular hemorrhage with diffuse white matter signal change (figure). CSF analysis was not performed due to clinical concerns

\section{Correspondence}

Dr. Green

c.green10@nhs.net

\section{MORE ONLINE}

\section{COVID-19 Resources}

For the latest articles, invited commentaries, and blogs from physicians around the world

NPub.org/COVID19

\section{MORE ONLINE}

$\rightarrow$ Teaching slides

links.lww.com/WNL/ B251

\footnotetext{
*These authors contributed equally to this work.
}

From the Gloucestershire Hospitals NHS Foundation Trust (C.G., H.M., P.S., F.G., J.S.), Gloucester; North Bristol NHS Trust (C.R., E.C.); and Cobalt Medical Charity (I.L.), Cheltenham, UK.

Go to Neurology.org/N for full disclosures. Funding information and disclosures deemed relevant by the authors, if any, are provided at the end of the article. 
Table Differential Diagnosis for Infective splenial Lesions

\begin{tabular}{l} 
Viral \\
\hline Influenza, coronavirus, rotavirus, measles, adenovirus, human parvovirus \\
B19, cytomegalovirus, varicella-zoster, adenovirus, rubella, human \\
herpesvirus-6, human herpesvirus-7, HIV, mumps, parainfluenza, \\
enterovirus, Epstein-Barr \\
Bacterial
\end{tabular}
Legionella pneumophila, Streptococcus pneumoniae, Salmonella enteritidis, Escherichia coli, Enterococcus faecalis, Klebsiella pneumoniae (febrile urinary tract infection), Campylobacter jejuni

Other

Mycoplasma pneumoniae, malaria, dengue fever

regarding raised intracranial pressure. Administration of high-dose corticosteroids led to clinical and radiologic improvement (figure).

The differential diagnosis of infective splenial lesions is presented (table). ${ }^{1}$ We consider the likely diagnosis to be acute disseminated encephalomyelitis with hemorrhage, adding to the clinical spectrum of neurologic complications of COVID-19 and highlighting the possibility of favorable outcome. $^{2}$

\section{Study Funding}

No targeted funding reported.

\section{Disclosure}

The authors report no disclosures relevant to the manuscript. Go to Neurology.org/N for full disclosures.
Appendix Authors

\begin{tabular}{|c|c|c|}
\hline Name & Location & Contribution \\
\hline $\begin{array}{l}\text { Christopher } \\
\text { Green, FRCR }\end{array}$ & $\begin{array}{l}\text { Gloucestershire } \\
\text { Royal Hospital, } \\
\text { UK }\end{array}$ & $\begin{array}{l}\text { Drafting/revision of the } \\
\text { manuscript for content, including } \\
\text { medical writing for content }\end{array}$ \\
\hline $\begin{array}{l}\text { Hamish } \\
\text { Morrison, } \\
\text { MRCP }\end{array}$ & $\begin{array}{l}\text { Gloucestershire } \\
\text { Royal Hospital, } \\
\text { UK }\end{array}$ & $\begin{array}{l}\text { Drafting/revision of the } \\
\text { manuscript for content, including } \\
\text { medical writing for content }\end{array}$ \\
\hline $\begin{array}{l}\text { Paul Smith, } \\
\text { FRCR }\end{array}$ & $\begin{array}{l}\text { Gloucestershire } \\
\text { Royal Hospital, } \\
\text { UK }\end{array}$ & $\begin{array}{l}\text { Drafting/revision of the } \\
\text { manuscript for content, including } \\
\text { medical writing for content }\end{array}$ \\
\hline $\begin{array}{l}\text { Farhad } \\
\text { Golestani, } \\
\text { FRCP, MD }\end{array}$ & $\begin{array}{l}\text { Gloucestershire } \\
\text { Royal Hospital, } \\
\text { UK }\end{array}$ & $\begin{array}{l}\text { Drafting/revision of the } \\
\text { manuscript for content, including } \\
\text { medical writing for content }\end{array}$ \\
\hline $\begin{array}{l}\text { Claire Rice, } \\
\text { FRCP, PhD }\end{array}$ & $\begin{array}{l}\text { North Bristol } \\
\text { NHS Trust, UK }\end{array}$ & $\begin{array}{l}\text { Drafting/revision of the } \\
\text { manuscript for content, including } \\
\text { medical writing for content }\end{array}$ \\
\hline $\begin{array}{l}\text { Elizabeth } \\
\text { Coulthard, } \\
\text { FRCP, PhD }\end{array}$ & $\begin{array}{l}\text { North Bristol } \\
\text { NHS Trust, UK }\end{array}$ & $\begin{array}{l}\text { Drafting/revision of the } \\
\text { manuscript for content, including } \\
\text { medical writing for content }\end{array}$ \\
\hline $\begin{array}{l}\text { Julie Searle, } \\
\text { FRCR }\end{array}$ & $\begin{array}{l}\text { Gloucestershire } \\
\text { Royal Hospital, } \\
\text { UK }\end{array}$ & $\begin{array}{l}\text { Drafting/revision of the } \\
\text { manuscript for content, including } \\
\text { medical writing for content }\end{array}$ \\
\hline $\begin{array}{l}\text { lain Lyburn, } \\
\text { FRCR }\end{array}$ & $\begin{array}{l}\text { Gloucestershire } \\
\text { Royal Hospital, } \\
\text { UK }\end{array}$ & $\begin{array}{l}\text { Drafting/revision of the } \\
\text { manuscript for content, including } \\
\text { medical writing for content }\end{array}$ \\
\hline
\end{tabular}

\section{References}

1. Blaauw J, Meiners LC. The splenium of the corpus callosum: embryology, anatomy, function and imaging with pathophysiological hypothesis. Neuroradiology 2020;62: 563-585.

2. Wang HY, Li XL, Yan ZR, et al. Potential neurological symptoms of COVID-19. The Adv Neurol Disord 2020;13:1756286420917830. 


\section{Neurology}

\section{Teaching Neuroimages: COVID-19-Associated Acute Disseminated Encephalomyelitis With Corpus Callosal Hemorrhage}

Christopher Green, Hamish Morrison, Paul Smith, et al.

Neurology 2021;96;e307-e308 Published Online before print October 14, 2020

DOI 10.1212/WNL.0000000000011001

This information is current as of October 14, 2020

\section{Updated Information \&} Services

\section{References}

Subspecialty Collections

Permissions \& Licensing

Reprints including high resolution figures, can be found at: http://n.neurology.org/content/96/2/e307.full

This article cites 2 articles, 0 of which you can access for free at: http://n.neurology.org/content/96/2/e307.full\#ref-list-1

This article, along with others on similar topics, appears in the following collection(s):

Acute disseminated encephalomyelitis

http://n.neurology.org/cgi/collection/acute_disseminated_encephalomy elitis COVID-19

http://n.neurology.org/cgi/collection/covid_19

Intracerebral hemorrhage

http://n.neurology.org/cgi/collection/intracerebral_hemorrhage

MRI

http://n.neurology.org/cgi/collection/mri

Viral infections

http://n.neurology.org/cgi/collection/viral_infections

Information about reproducing this article in parts (figures,tables) or in its entirety can be found online at:

http://www.neurology.org/about/about_the_journal\#permissions

Information about ordering reprints can be found online:

http://n.neurology.org/subscribers/advertise

Neurology ${ }^{\circledR}$ is the official journal of the American Academy of Neurology. Published continuously since 1951, it is now a weekly with 48 issues per year. Copyright (C 2020 American Academy of Neurology. All rights reserved. Print ISSN: 0028-3878. Online ISSN: 1526-632X.

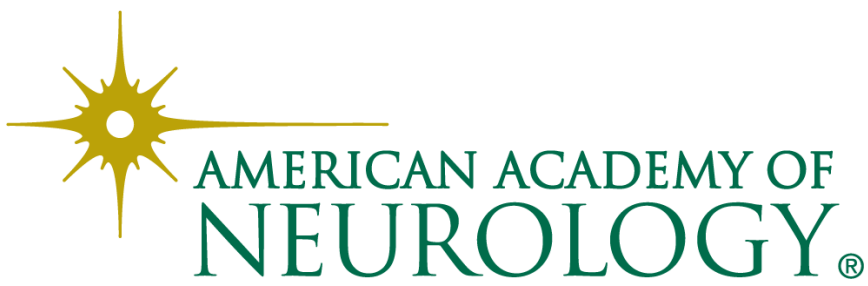

